\title{
RECORD NESTING YEAR FOR GREAT GRAY AND NOTHERN HAWK OWLS IN RIDING MOUNTAIN NATIONAL PARK REGION DURING THE SPRING OF 2009
}

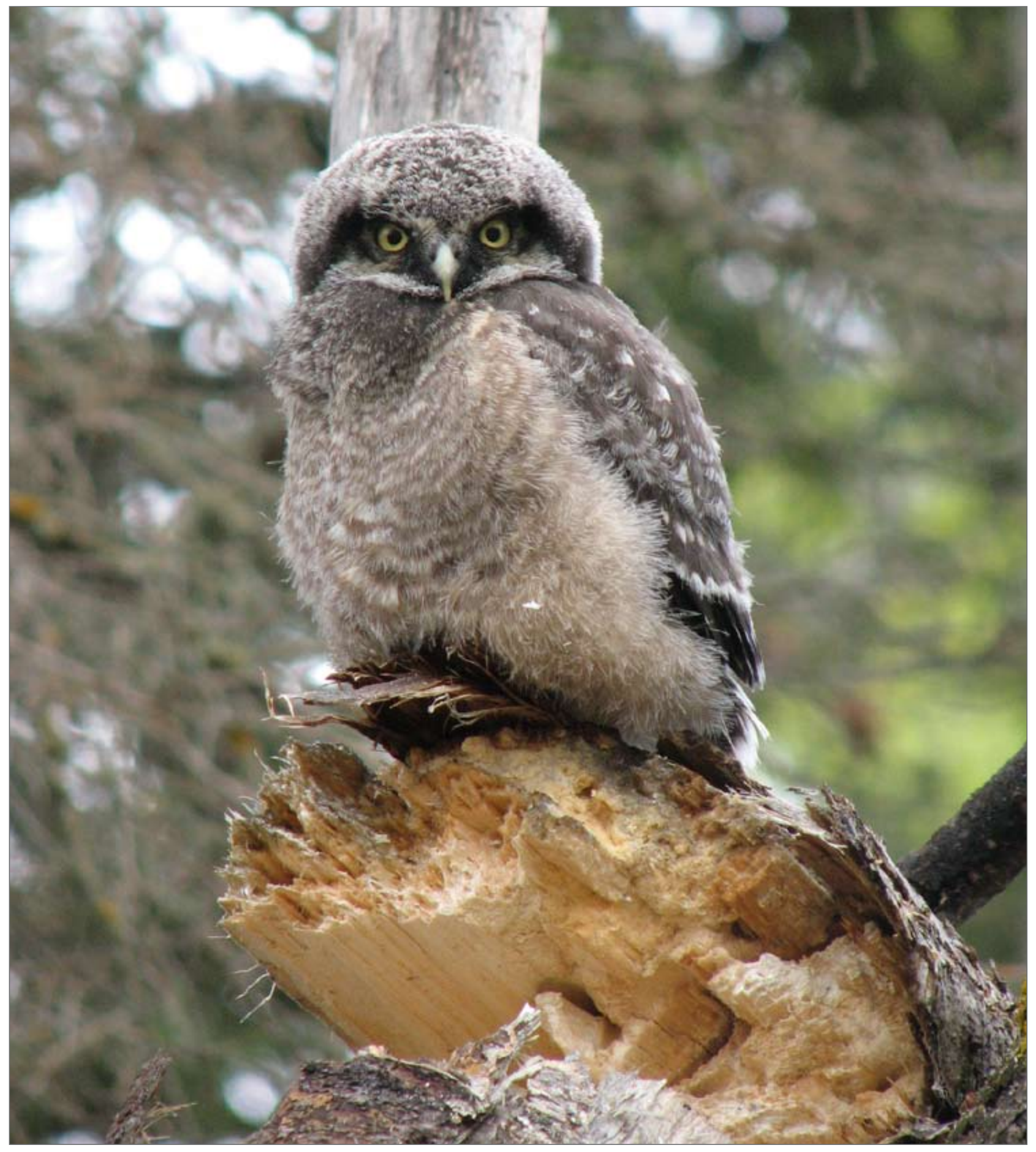




\section{Ken Kingdon}

Box 314, Onanole, MB R0J 1N0

ken.kingdon@pc.gc.ca

The spring of 2009 proved to be a record year for breeding Great Gray Owls (GGOW) (Strix nebulosi) and Northern Hawk Owls (NHOW) (Surnia ulula) in and around Riding Mountain National Park (Table 1).

Riding Mountain National Park has been a known breeding area for GGOWs for decades, with the author recording at least one nest every two-to-three years since 1991 in or near the Park. However, the spring of 2009 proved to be a record year, with evidence of breeding, including active nests and/or fledged young found within a relatively small area (Figure 1).

The spring of 2009 also provided the first breeding record for NHOWs in Riding Mountain National Park (RMNP unpublished data). Another NHOW breeding record was located east of the park and just west of Lake Manitoba (Figure 1). These records appear to be the most southerly for NHOW in southwestern Manitoba. The closest breeding records for NHOW are about $30 \mathrm{~km}$ to the north of these 2009 records. ${ }^{1}$

The lack of breeding records in southwestern Manitoba is possibly due to either a lack of appropriate habitat or search effort. Eastern Manitoba has records of NHOW breeding as far south as the $49^{\circ}$

$\mathrm{N}$ parallel and there are breeding records extending into boreal forest habitats of adjacent Minnesota. ${ }^{1,2}$ More recently, Manitoba's Breeding Bird Atlas, conducted between 2010 and 2014, had no confirmed records of Northern Hawk Owls breeding in the southwest portion of Manitoba, although there were two records, both rated as "possible nests," with one located to the south of the Park and one to the northeast. ${ }^{3}$ No details were available for these two records from the online data provided by the Manitoba breeding bird atlas website. $^{3}$

\section{As both GGOW and NHOW} are among the most diurnal of Manitoba's owl species (along with Snowy and Short-eared Owls), and with their habit of sitting in conspicuous locations (year-round for NHOW, in winter only for GGOW), these two species are relatively easy

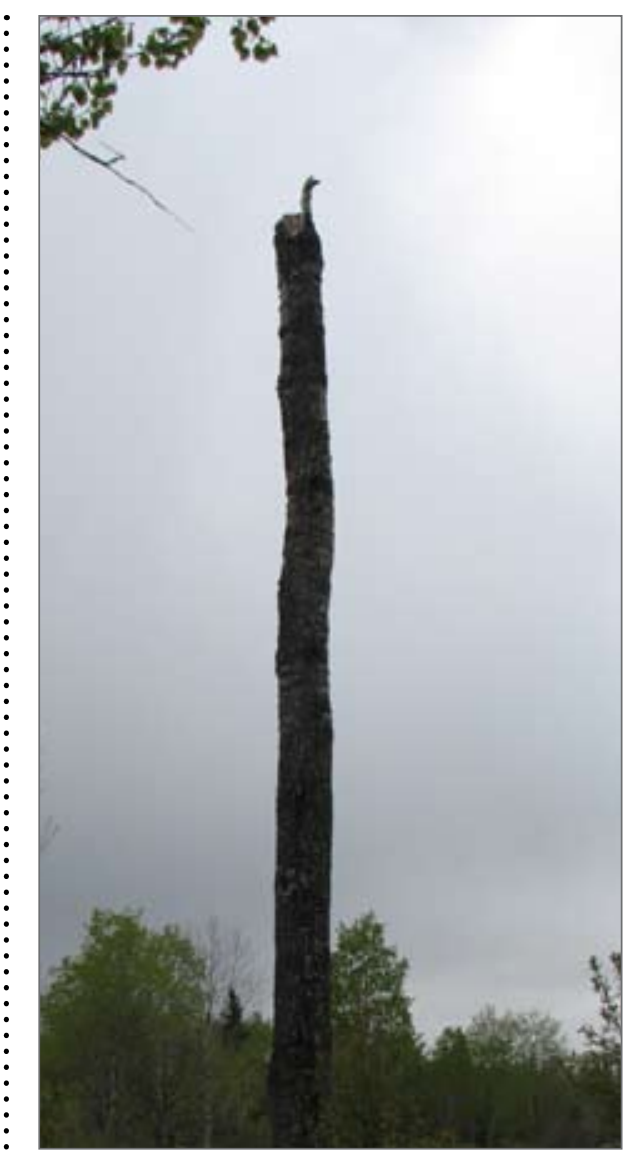

Nesting site of Northern Hawk Owl, June 2009 Photo credit: Ken Kingdon

\section{TABLE 1: Owl breeding observations for Riding Mountain National Park region, spring of 2009.}

\begin{tabular}{|c|c|c|c|c|c|c|c|}
\hline SPECIES & DATES OBSERVED (2009) & LOCATION (UTM 14U) & ADULTS & YOUNG OF YEAR (YOY) & NEST & COMMENTS & OBSERVER \\
\hline NHOW (Pair 1) & May $29 \& 31$, June 9 & 04119055630050 & 2 & 5 & yes & & KK \\
\hline NHOW (Pair 2) & May & 05047855636356 & 1 & suspected & no & Territorial calls heard & $\mathrm{CH}$ \\
\hline GGOW (Pair 1) & June30 & 04158005625000 & 2 & 3 & no & Fledged young & $\mathrm{CD} / \mathrm{JI}$ \\
\hline GGOW (Pair 2) & May 31 & 04127405628450 & 2 & $\begin{array}{l}\text { begging calls heard } \\
\text { but unable to find nest }\end{array}$ & no & $\begin{array}{r}\text { May be same breeding pair } \\
\text { as GGOW Pair } 1\end{array}$ & KK \\
\hline GGOW (Pair 3) & April 26, June 19 & 04350455608630 & 2 & $\begin{array}{r}1+1 \text { non-viable egg } \\
\text { in nest }\end{array}$ & yes & YOY observed several times & KK/KM \\
\hline GGOW (Pair 4) & July 18 & 04124005633190 & 1 & 3 & no & Fledged young & KK \\
\hline GGOW (Pair 5) & May/June & 04457555596814 & 2 & unknown & yes & $\begin{array}{r}\text { At least one fledged young } \\
\text { observed }\end{array}$ & KM \\
\hline
\end{tabular}


to observe when present, especially in winter and early spring. Two of the GGOW breeding locations and one of the NHOW suspected breeding sites were discovered following several repeated sightings of adult owls in the immediate nesting area during the spring. At the same time, during the winter and spring season of 2009, a NHOW was observed several times approximately 14 $\mathrm{km}$ (straight line distance) south of where the nest of NHOW Pair 1 was subsequently discovered. While it is unknown whether this bird was one of the breeding adults, it does appear likely given the close proximity of the winter sightings to the breeding site.

Of interest, the two adult GGOWs indicated as GGOW Pair 2 were observed by the author in an open meadow two times over the spring months. These adults, when observed in flight, always appeared to arrive from the east or southeast. These adults were 4.7 to $4.9 \mathrm{~km}$ straight line distance northwest of the adults and fledged young observed on June 30 by Jim Irwin and Celes Davar, designated as GGOW Pair 1. Given the dates of the sighting of the adults by the author and the sighting of fledged young by Irwin and Davar, these two records represented different breeding pairs as young owls do not disperse that far in June. While male GGOWs may fly up to $3.2 \mathrm{~km}$ from the nest while hunting for young, the timing of the observed behaviour at GGOW Pair 2 indicates that the nest was nearby and far enough from GGOW Pair 1 to be separate breeding records. The proximity of the GGOW breeding records suggests a plentiful local food supply as GGOW nesting densities in Manitoba have been recorded as high 1.88 pairs $/ \mathrm{km}^{2}$ during periods of high small mammal populations. $^{4}$
A review of winter 2008/2009 Christmas Bird Count $(\mathrm{CBC})^{5}$ data suggests it was a poor predictor of the increase in observed owl breeding activity during the spring 2009. One GGOW was seen during the count period, but this is well within the average sighting of one GGOW every two years ( $n=19$ birds over 41 counts) (RMNP unpublished data). Thus the local CBC area (centred in the area of Wasagaming, Riding Mountain National Park) showed no increase in the presence of owls, with no NHOW observed. This is not surprising since both species are able to migrate great distances in winter and settle to breed in areas with high prey availability within weeks of nesting.

Nor did the spring 2009 annual nocturnal owl survey ${ }^{6}$ hint at the subsequent breeding documented herein, with no GGOW nor NHOW counted on the five routes surveyed and centred in the central portion of Riding Mountain National Park (RMNP unpublished data). It should be noted, however, that all of the breeding sites were more than one kilometre in distance from the survey routes, and therefore calling GGOW and NHOW would not have been detected during the surveys.

Both GGOW and NHOW are known to prey on voles year-round, and GGOW are particularly well adapted for hunting them under snow. ${ }^{2,4}$ A lack of local small mammal population trend data suggests such surveys could be useful to understand owl and other predator trends over time. It is likely that the observed increase in breeding owls correlated to an increase in small mammals during this period.

Spring and summer 2009 provided unprecedented opportunities to view both GGOW and NHOW in the Riding Mountain National Park region. Due to the unpredictable nature of these events, it is hoped that when another breeding event like this occurs, more data will be gathered on these predators and their prey to better understand these icons of the boreal forest.

A final footnote. In April 2017, an active GGOW nest was observed within $0.5 \mathrm{~km}$ of the 2009 nesting site of GGOW Pair 2. Additionally, on June 7, 2017, three fledged NHOW young of year were observed within 50 metres of the 2009 nest location of NHOW Pair 1. These observations demonstrate that the ecological requirements for nesting success for both NHOW and GGOW remain within the area. It is hoped that these same conditions continue to persist for another eight years, and more.

I'd like to thank the following for providing details on owl observations: Kurt Mazur, Chris Higgs, Celes Davar, and Jim Irwin. I would also like to thank the anonymous editor who greatly improved the article.

1. Duncan, J. R. and Duncan, P. A. (2003) Northern Hawk Owl. In: Taylor, P. (Ed.) Birds Of Manitoba. Manitoba Naturalists Society, Winnipeg. p. 229-230.

2. Duncan, J. R. and Duncan, P. A. (2014). Northern Hawk Owl. The Birds of North America (Poole, A., Ed.) Ithaca: Cornell Laboratory of Ornithology; Retrieved March 17, 2017, from: https://birdsna.org/SpeciesAccount/bna/species/nohowl/

3. Manitoba Breeding Bird Atlas (2015). Breeding evidence map for northern hawk owl. Retrieved from www.birdatlas.mb.ca on March 17, 2017.

4. Bull, E. L., and Duncan, J. R. (1993). Great Gray Owl. The Birds of North America (Poole, A., Ed.) Ithaca: Cornell Laboratory of Ornithology; Retrieved March 17, 2017, from: https://birdsna.org/Species-Account/bna/ species/grgowl/

5. National Audubon Society (2009). The Christmas Bird Count Historical Results; Retrieved March 17, 2017, from: http:/www. christmasbirdcount.org.

6. Bird Studies Canada. Guidelines for Nocturnal Owl Monitoring in North America. Retrieved May 24, 2017, from: http://www. birdscanada.org/volunteer/natowls/ 